\title{
Agronomic Management of Foxtail millet (Setaria italica L.) in India for Production Sustainability: A Review
}

\author{
Sagar Maitra*1, Sandipan Pine ${ }^{1}$, Tanmoy Shankar ${ }^{1}$, Arunabha $\mathrm{Pal}^{1}$ and \\ Biswajit Pramanick ${ }^{2}$
}

${ }^{1}$ Centurion University of Technology and Management, Paralakhemundi - 761211, Odisha, India

${ }^{2}$ Dr. Rajendra Prasad Central Agricultural University, Pusa - 848125, Samastipur, Bihar, India

*Corresponding author: sagar.maitra@cutm.ac.in

Received: $14-01-2020$

Revised: $19-04-2020$

Accepted: 22-05-2020

\begin{abstract}
Since ancient period, different small millets are in use as food and animal feed. But during last few decades, fine cereals and their value-added products were promoted in India and millets were neglected. Recently, small millets are recognized as nutri-cereals due to their nutritional values. These crops are ecologically sound, can enrich agro-diversity, check erosion in arid regions, sequester carbon and assure food and nutritional security to smallholders in drylands. But productivity of small millets is less compared to other cereals. Like other small millets, foxtail millet (Setaria italica L.) is also rich in nutrients and as a short duration crop it fits to different cropping systems. Sufficient research work has not been carried out on agronomic management targeting higher productivity. An initiative has been taken to gather information from available literature on improved agronomic management of foxtail millet and presented in the article. Further, the article highlighted the future scope of research on the crop.
\end{abstract}

Keywords: Foxtail millet, agronomic management, varieties, nutrient management, cropping system, sustainability, drylands

Millets are ancient grains used as food, feed and forage since the Neolithic age. Among different millets, pearl millet (Pennisetum glaucum L.) and sorghum (Sorghum bicolor L.) are known as major millets and rest are grouped into small millets. India is the leading country in small millets production with acreage of around 7.0 lakh ha and productivity of $633 \mathrm{~kg} \mathrm{ha}^{-1}$ (Maitra and Shankar, 2019). The small millets are cultivated as mainly rainfed in uplands of arid and semi-arid regions with sub-optimum level of management (Maitra et al. 1997; 1998). In India, after green revolution main focus was given on production of fine cereals, namely, rice and wheat and millets became neglected grains. Further, urbanization, increase of income and change of food habit also made millets as poor-man's food. But during recent time, millets have regained their lost pride due to re-evaluation of nutritional qualities
(Maitra, 2020). Small millets are rich in protein, energy, dietary fibre and having neutraceutical properties (Banerjee and Maitra, 2020). Moreover, small millets are known as miracle-crops because of their multiple uses. Presently, agriculture is facing tremendous problem due to climate change and global warming. The main effects of climate change are increase in temperature, uncertainties in rainfall and enhancement of greenhouse gasses emission (mainly carbon-dioxide). As $\mathrm{C}_{4}$ plants, millets can use enhanced atmospheric $\mathrm{CO}_{2}$ and convert into biomass (Brahmachari et al. 2018). Millets are the ecologically sound crops which can withstand

How to cite this article: Maitra, S., Pine, S., Shankar, T., Pal, A. and Pramanick, B. (2020). Agronomic Management of Foxtail millet (Setaria italica L.) in India for Production Sustainability: A Review. International Journal of Bioresource Science, 7(1): 11-16.

Source of Support: None; Conflict of Interest: None 
under warm and drought conditions with low carbon footprint in agriculture and hence these are considered as climate-smart crops.

Among different small millets, foxtail millet (Setaria italica L.) has the heritage of Asian origin and was domesticated in central China during ancient period (Miller et al. 2016). Like other millets it belongs to Poaceae family and a member of the subfamily Panicoideae. Foxtail millet is nutrient rich and each $100 \mathrm{~g}$ of edible portion contains fibre $2.4 \mathrm{~g}$, protein $12.3 \mathrm{~g}$, carbohydrates $60.9 \mathrm{~g}$, fat $4.3 \mathrm{~g}$, calcium $31 \mathrm{mg}$, iron $2.8 \mathrm{mg}$, phosphorus $290 \mathrm{mg}$, minerals $3.3 \mathrm{~g}$ and food energy $331 \mathrm{KCal}$ (Vanithasri et al. 2012; Banerjee and Maitra, 2020).Foxtail millet is mainly cultivated in dry regions of India as rainfed crop as the crop shows great tolerance under drought conditions. In India, the cultivation of foxtail millet is confined southern states, namely, to Andhra Pradesh, Karnataka, Tamil Nadu and Telengana, also to some extent grown in Bihar, Uttar Pradesh and Uttarakhand. The average productivity of small millets including foxtail millets is less, but presently improved varieties have been developed which are having enough potential. Choice of improved varieties and proper agronomic management are key concerns to maximize productivity of foxtail millet and research in the line of agronomic management may be intensified. In the present article, an initiative has been taken to review the agronomic management practices based on available literature for boosting yield of foxtail millet.

\section{Improved varieties and uniform stand establishment}

Foxtail millet can be grown in tropics as well as in temperate regions. But in India, it is cultivated in drylands of tropics in marginal lands mainly under rainfed conditions as it has tolerance to moisture stress. Generally, small and marginal farmers cultivate local varieties of foxtail millet with suboptimal level of management and inferior plant stand. Stand establishment is important to obtain satisfactory yield and it is dependent on sowing of quality seeds at optimum spacing and uniform germination. There are some state specific improved varieties in India which can be cultivated for better productivity (Table 1).

The field experiments conducted at different locations clearly indicated that improved varieties of foxtail millet yielded more than the average productivity of small millets. Navya Jyothi et al. (2016) observed that the foxtail varieties SiA 3088, SiA 3085, SiA 3156 and Srilaxmi produced grain yield of 1001 to $1141 \mathrm{~kg} \mathrm{ha}^{-1}$ under rainfed conditions in kharif season at Tirupati, Andhra Pradesh. In another experiment at Naira, Andhra Pradesh, Ramyasri et al. (2018) observed that the variety SiA 3156 yielded more $\left(1290 \mathrm{~kg} \mathrm{ha}^{-1}\right)$ than other two varieties, namely, SiA 3085 and SiA 3088 during rabi season. Foxtail millet variety SiA 2644 performed better than HMT-1 and local varieties in red sandy clay soil of southern transition zone of Karnataka during kharif season (Nandini and Sridhara, 2019a). But at Prayag, Uttar Pradesh, the variety SiA 326 (Prasad) gave more yields in kharif season than SiA 3156 in sandy loam soil (Selectstar Marwein et al. 2019).

Foxtail millet is generally cultivated as kharif crop and before onset of monsoon preparatory tillage is made. After onset of monsoon, field is harrowed or ploughed and seeds are sown. The resource poor farmers usually broadcast the seeds $(15 \mathrm{~kg}$ $\left.\mathrm{ha}^{-1}\right)$, but line sowing is always preferred as less seeds are required $\left(810 \mathrm{~kg} \mathrm{ha}^{-1}\right)$ and optimum

Table 1: Foxtail millet varieties cultivated in different states of India

\begin{tabular}{ll}
\hline State & Vatieties of foxtail millet \\
\hline Andhra Pradesh & SiA 2644, SiA 3085, SiA 3088, SiA 3156, SiA 3085, Lepakshi, SiA 326, Narasimharaya, Krishnadevaraya, \\
& PS-4, Srilaxmi \\
Karnataka & SiA 326, HMT 100-1, PS 4,Narasimharaya, SiA 3088, SiA 3156, SiA 3085, DHFt-109-3 \\
Tamil Nadu & TNAU 43, TNAU-186, TNAU 196, CO 1, CO 2, CO 4, CO 5, K2, K3, SiA 3088, SiA 3156, SiA 3085, PS-4 \\
Rajasthan & PrathapKangani (SR 1) and SR 51, SR 11, SR 16, SiA 3085, SiA3088, SiA-3156, PS 4 \\
Uttar Pradesh & PRK 1 and PS 4, SiA 326 (PRASAD), SiA 3156, SiA 3088, SiA 3085, Sreelaxmi, Narasimharaya, S-114, PS-4 \\
Uttarakhand & PS 4 and PRK 1, Sreelaxmi, SiA 326, SiA 3088, SiA 3156, SiA 3085, PS 4 \\
Bihar & RAU-1, SiA 3088, SiA 3156, SiA 3085, PS 4 \\
\hline
\end{tabular}

Source: Chapke et al. (2018) and others. 
stand establishment can be obtained. In case of line sowing, a row to row of $25-30 \mathrm{~cm}$ and within row between plants $8-10 \mathrm{~cm}$ distance is maintained (Chapke et al. 2018). But Nandini and Sridhara (2019a) in a study obtained more grain yield of foxtail millet with a spacing of $20 \mathrm{~cm} \times 10 \mathrm{~cm}$ in Karnataka which was probably due to more plant stand. In an experiment, using tractor drawn seed drill for line sowing gave higher grain yield (55\%) compared to farmers practice (AICRPSM, 2017).

In Andhra Pradesh and Maharashtra, foxtail millet is sown between first and third week of July. But in Uttar Pradesh and Bihar sowing starts from mid-June. However, in Karnataka, June- August is considered as sowing period for foxtail millet. In Tamil Nadu two crops are grown, kharif crop is sown in June-July, whereas summer irrigated crop is seeded in January. In general during rabi season foxtail millet is sown during September-October. Experimental results revealed that sowing time has a great impact on productivity of foxtail millet. Mubeena et al. (2019) recorded that sowing of foxtail millet during second fortnight of June and first fortnight of July yielded more than the crop sown during second fortnight of July or first fortnight of August in black soils of Raichur, Karnataka. Similarly, Nandini and Sridhara (2019b) also noted the crop sown on June 30 found to produce significantly more grain yield (2049.25 kg ha-1) and straw yield (4261.56 $\mathrm{kg} \mathrm{ha}^{-1}$ ) as compared to July 30 and August 30 sown foxtail millet in an experiment carried out at Shivamogga, Karnataka.

\section{Seed priming}

In dry regions, seed priming with growth regulating chemicals and bio-inoculants is effective for seedling vigour, growth and productivity as noted in small millets (Maitra et al. 1999). Gangadharayya et al. (2019) observed that seed priming in foxtail millet was effective in terms of growth and productivity of foxtail millet as they observed that seed priming with Azospirillum (20\%) + Pseudomonas fluorescens $(20 \%)+$ Phosphobacter $(20 \%)+\mathrm{Zn} \mathrm{SO}_{4}(0.1 \%)+$ Boron $(0.1 \%)$ recorded enhancement of growth and productivity of foxtail millet during kharif season. In the study hydro-priming was also yielded more than without priming (1610 and $1480 \mathrm{~kg} \mathrm{ha}^{-1}$ respectively).

\section{Nutrient management}

Foxtail millet is cultivated in India in resourcepoor soils and best agronomic management is not provided. But improved varieties of foxtail millet respond well to fertilizers. To obtain good productivity as well as to maintain soil health, adoption of Integrated Nutrient Management (INM) is advised. In general, application of 5 to 10 t FYM and $40 \mathrm{~kg} \mathrm{~N}, 20 \mathrm{~kg} \mathrm{P}_{2} \mathrm{O}_{5}$ and $20 \mathrm{~kg} \mathrm{~K} \mathrm{~K}_{2} \mathrm{O}$ is recommended (Chapke et al. 2018). FYM is applied during primary tillage and half of $\mathrm{N}$, entire quantity of $20 \mathrm{~kg} \mathrm{P}_{2} \mathrm{O}_{5}$ and $20 \mathrm{~kg} \mathrm{~K} \mathrm{O}$ are applied as basal fertilizer. Remaining half of $\mathrm{N}$ is applied after 3 to 4 weeks of sowing. Agronomic trials revealed that foxtail millet yield more with higher dose of $\mathrm{N}$ application than recommended. In Andhra Pradesh, at Tirupati application of $50 \mathrm{~kg} \mathrm{~N}$ gave more productivity (Nandini et al. 2018), however, at Naira maximum yield was obtained with 80 kg N (Ramyasri et al. 2018). Further, combined application of $\mathrm{N}$ and $\mathrm{P}_{2} \mathrm{O}_{5} @ 60 \mathrm{~kg}$ and $40 \mathrm{~kg} \mathrm{ha}{ }^{-1}$ resulted in higher productivity of foxtail millet in south Odisha (Reddy et al. 2019). Upendranaik et al. (2018) observed that a combination of different organic manures along with mulching increased growth and productivity of foxtail millet. Rafi et al. (2012) and Rafi and Charyulu (2016) reported that inoculation of Azospirillum sp. and phosphate solubilizing bacterium (PSB) individually and combined inoculation improved the yield of foxtail millet. Experimental results indicated that INM in foxtail millet yielded better. Application of $50 \% \mathrm{RDF}+25 \% \mathrm{~N}$ as neem cake + Azophos recorded higher grain yield in sandy loam read soils at Madurai, Tamil Nadu than 100\% RDF (44:22:0 kg N:P ${ }_{2} \mathrm{O}_{5}: \mathrm{K}_{2} \mathrm{O}$ ha $^{-1}$ ) and absolute control (Monisha et al. 2019). However, Kumaran and Parasuraman (2019) recorded that INM increased grain yield of foxtail millet at Tiruvannamalai, Tamil Nadu and combined application of farmyard manure, recommended dose of fertilizer and foliar application of 3\% Panchagavya at 20 days after sowing gave the maximum grain yield $(1652.5 \mathrm{~kg}$ ha $\left.^{-1}\right)$. INM with $75 \%$ RD N through Urea $+25 \% \mathrm{~N}$ through PM + Azospirillum seed inoculation gave maximum grain yield (2.31 t ha-1) at Prayagraj, Uttar Pradesh (Selectstar Marwein et al. 2019). 


\section{Weed management}

Generally, grassy, sedges and broad leaves weed are observed in foxtail millet field (Table 2). Intercultivation for two times and one hand weeding in line sown crop and two hand weeding in broadcost crop are useful for effective weed control. Moreover, post-emergence application of 2, 4-D sodium salt (80\%) @ $1.0 \mathrm{~kg}$ a.i. ha ${ }^{-1}$ at $20-25$ days after sowing (DAS) is effective for controlling broadleaved weeds. Isoproturon @ $1.0 \mathrm{~kg}$ a.i. ha ${ }^{-1}$ as pre-emergence spray is also effective in weeds control (Chapke et al. 2018). But AICRPSM (2017) stated that pre-emergence application of Oxadiargyl @ 70 gm/ha or Pretilachlor $@ 0.75 \mathrm{~kg} / \mathrm{ha}$ was effective in weed management of foxtail millet.

Table 2: Common weeds of foxtail millet

\begin{tabular}{ll}
\hline Category & Scientific name \\
\hline Grass & Echinochloa colonum, Enhinochloacrus \\
& gulli, Dactyloctenium aegypticum, \\
& Elusine indica, Setaria glauca, Cynodon \\
& dactylon, Phragmites karka, Cyperus \\
& rotundus, Sorghum halepanse \\
Sedge & Cyperus rotundus (motha) \\
Broad-leaved & $\begin{array}{l}\text { Celosia argentia, Commelina } \\
\text { benghalensis, Phylanthusniruri, } \\
\\
\text { Solanum nigrum and Amaranthus } \\
\text { viridis }\end{array}$ \\
\hline
\end{tabular}

\section{Water management}

As a rainfed kharif crop foxtail millet is cultivated in drylands. But intermittent gap between rainy spells may occur and life-saving irrigation can be given if water is available. But where it is grown in rabi season, crop should be irrigated. Chapke et al. (2018) suggested providing two irrigations, at 25-30 and 45-50 DAS. Experimental results revealed that pre- sowing irrigation and irrigation at 20-25 and 40-45 days after sowing of foxtail millet was found to significant and gave higher productivity (AICRPSM, 2017).

\section{Cropping system}

Foxtail millet is such a crop which can be included easily in different sequential cropping. Growing of foxtail millet-mustard, foxtail millet-green gram, foxtail millet-pigeon pea and foxtail milletsunflower are profitable than mono-cropping of foxtail millet. Relay cropping can also be practiced. In Andhra Pradesh, if monsoon sets early, foxtail millet is sown with a row spacing of $45 \mathrm{~cm}$ and rabi sorghum is introduced as relay crop when foxtail millet is close to maturity stage (Chapke et al. 2018).

Foxtail millet is a suitable crop for intercropping. Intercropping is advantageous in many ways as it assures greater resource use, reduction of population of harmful biotic agents, higher resource conservation and soil health and more production and sustainability of the system (Maitra et al. 2019). In intercropping system, more than one crop are grown together on the same land and utilize the soil nutrients, soil moisture, atmospheric $\mathrm{CO}_{2}$ and sunlight. The resource conservation and soil health aspects are also positive effects of intercropping system as it checks run-off of water, soil erosion and less nutrient loss from the soil. Moreover, it facilitates soil fertility enhancement when small millets are intercropped with legumes and enables diversity of beneficial soil microorganisms. In intercropping system, complementarity among the species cultivated is very much important for increasing crop yields. Under dryland conditions intercropping system provides a natural insurance against total crop failure and thus production sustainability. Though enough research work on foxtail millet based intercropping system was not carried out, the advantages of intercropping was noted by researchers over sole cropping. Experimental results revealed that intercropping of green gram or black gram with foxtail millet at 3:3 ratios is beneficial (AICRPSM, 2017). In Andhra Pradesh, intercropping system with foxtail millet + ground nut (2:1) and foxtail millet + cotton (5:1) are very common, whereas at Rayalseema region of Andhra Pradesh, intercropping of foxtail millet and pigeon pea (5:1) is preferred.

Himasree et al. (2017) carried out an experiment in late kharif conditions in acidic soils of Rayalseema region of Andhra Pradesh and concluded that more gross and net incomes and benefit-cost ratio were obtained with the sowing of foxtail millet + pigeonpea (5:1) with sowing during first fortnight of August. Further, the land equivalent ratio (LER), Area Time Equivalent Ratio (ATER) and foxtail millet grain equivalent yield were more with the intercropping system of foxtail millet + pigeonpea (5:1) sown during the first fortnight of August 
in late kharif. In another study, Manjunath and Salakinkop (2017) showed that intercropping of soybean + foxtail millet at row proportion of 2:1 and $4: 2$ recorded that advantageous LER values (1.49 and 1.50 respectively) and higher benefit: cost $(\mathrm{B}: \mathrm{C})$ ratio (2.39 and 2.45 respectively). Manjunath $e t$ al. (2018) reported that superiority of intercropping pigeonpea + foxtail millet (1:2) as higher net returns ( $₹ 111457 \mathrm{ha}^{-1}$ ) and benefit cost ratio of 3.79 were recorded over sole cropping. Moreover, groundnut + foxtail millet (6:1) registered more land resource use efficiency as marginal increase of LER value (1.14) and higher $B: C$ ratio (2.23) as against $B: C$ ratio of sole groundnut of 2.14 and sole foxtail millet of 1.23 (Shwethanjali et al. 2018). The studies clearly indicated yield advantages, efficient utilization of resources and economic returns with foxtail millet with different intercrop combinations.

\section{Future scope of research}

The research evidences and literary sources clearly indicate that enough research has not been carried out on foxtail millet. Considering the importance, present demand and nutritional value of the crop, research work should be carried out in the following directions.

- Varietal improvement and evaluation of promising varieties of foxtail millet should be conducted for different agro-climatic regions under different cropping systems.

- Research may be intensified on time of sowing, spacing and plant population for assuring optimum stand.

- Efficient nutrient management trials like soil test crop response and site specific nutrient management may be carried out for target yield.

- Studies on response to different micro-nutrient and management are needed considering the deficiency occurred in different soils.

- Contingency measures and need-based agronomic management with manipulation of planting geometry, plant population and nutrient management under aberrant situation should be in focus for drylands.

- Water management studies for rabi crop is also needed.
- Intensive study on cropping system and intercropping should be carried out targeting production sustainability of drylands.

\section{CONCLUSION}

Yield enhancement of foxtail millet can be made possible through release of location specific varieties and their adoption at farmers' level. Moreover, adoption of appropriate agronomic management like proper sowing time and spacing to assure uniform stand, nutrient, water and weed management are important to boost productivity of foxtail millet. Cropping system and intercropping system can help in achieving more yield and return and provide income and livelihood security in drylands. But, there is enough scope for further research on foxtail millet like nutrient management trials based on soil test crop response (STCR) and site specific nutrient management (SSNM) for target productivity, micro-nutrient management, contingency crop management and intensive study in intercropping combinations and proportions for sustaining productivity of drylands.

\section{REFERENCES}

1. AICRPSM, 2017. Annual progress report: 2016-17, AICRP on Small Millets, 2. Agronomy, Bengaluru, pp.10, available at: http://www.aicrpsm.res.in/Downloads/Reports/2Agronomy-report.pdf (accessed on: 12 March, 2020)

2. Banerjee, P. and Maitra, S. 2020. The role of small millets as functional food to combat malnutrition in developing countries. Indian Journal of Natural Sciences, 10(60): 2041220417.

3. Brahmachari, K., Sarkar, S., Santra, D.K. and Maitra, S. 2018. Millet for food and nutritional security in drought prone and red laterite region of eastern India, International Journal of Plant \& Soil Science, 26(6): 1-7.

4. Chapke, R.R., Prabhakar, Shyamprasad, G., Das, I.K. and Tonapi, V.A. 2018. Improved millets production technologies and their impact. Technology Bulletin, ICARIndian Institute of Millets Research, Hyderabad 500 030, India, pp. 52-56. ISBN: 81-89335-69-3.

5. Gangadharayya, S.H., Prashant, S.M., Shakuntala, N.M., Kumar, K.V., Yogeesh, L.N. and Krishnamurthy, D. 2019. Influence of seed priming with chemicals, micronutrients and bio-inoculants on growth and yield attributes in foxtail millet (Setaria italica L.). Int. J. Curr. Microbiol.App. Sci., 8(10): 1896-1901.

6. Himasree, B., Chandrika, V., Sarala, N.V. and Prasanthi, A. 2017. Evaluation of remunerative foxtail millet (Setaria italica L.) based intercropping systems under late sown conditions. Bull. Env. Pharmacol. Life Sci., 6(3): 306-308. 
7. Kumaran, G. and Parasuraman, P. 2019. Effect of enriched FYM and Panchagavya spray on foxtail millet (Setaria italica) under rainfed conditions. International Journal of Chemical Studies., 7(2): 2121-2123.

8. Maitra, S. 2020. Potential horizon of brown-top millet cultivation in drylands: A review. Crop Res., 55(1\&2): 57-63.

9. Maitra, S. and Shankar. T. 2019. Agronomic management in little millet (Panicum sumatrense L.) for enhancement of productivity and sustainability. IJBS, 6(2): 91-96.

10. Maitra, S., Ghosh, D. C. Sounda, S., Jana, P.K. and Roy, D.K. 1998. Effect of seed treatment on growth and productivity of finger millet under rained lateritic belt of West Bengal. Indian Agriculturist, 42(1): 37- 43.

11. Maitra, S., Jana, P. K., Ghosh, D.C., Sounda, G. and Roy D.K. 1999. Effect of varieties and pre-sowing seed treatment on yield, quality and nutrient uptake by finger millet under lateritic belt of West Bengal. Annals of Agricultural Research, 20(3): 360-364.

12. Maitra, S., Palai J.B., Manasa, P., Prasanna Kumar D. 2019. Potential of intercropping system in sustaining Crop sroductivity. International Journal of Agriculture, Environment and Biotechnology, 12(1): 39-45.

13. Maitra, S., Sounda, S., Ghosh, D.C. and Jana, P.K. 1997. Effect of seed treatment on finger millet (Eleusine coracana) varieties in rainfed upland. Indian Journal of Agricultural Sciences, 67(10): 478-480.

14. Manjunath, M.G. and Salakinkop, S.R. 2017. Growth and yield of soybean and millets in intercropping systems. J. Farm Sci., 30(3): 349-353.

15. Manjunath, M.G., Vajjaramatti and Kalaghatagi, S.B. 2018. Performance of pigeonpea and millets in intercropping systems under rainfed conditions. Journal of Farm Sciences, 31(2): 199-201.

16. Miller, N.F., Spengler, R.N. and Frachetti, M. 2016. Millet cultivation across Eurasia: Origins, spread, and the influence of seasonal climate. The Holocene 1-10, https:// doi.org/10.1177/0959683616641742

17. Monisha, V., Rathinaswamy, A., Mahendran, P.P. and Kumutha, K. 2019. Influence of integrated nutrient management on growth attributes and yield of foxtail millet in red soil. International Journal of Chemical Studies, 7(3): 3536-3539.

18. Mubeena, P., Halepyati, A.S. and Chittapur, B.M. 2019. Effect of date of sowing and nutrient management on nutrient uptake and yield of foxtail millet (Setaria italica L.). International Journal of Bio-resource and Stress Management, 10(1):092-095.

19. Nandini, K.M. and Sridhara, S. 2019a. Response of growth, yield and quality parameters of foxtail millet genotypes to different planting density. Int. J. Curr. Microbiol. App. Sci., 8(02): 1765-1773.
20. Nandini, K.M. and Sridhara, S. 2019b. Performance of foxtail millet (Setaria italica L.) genotypes to sowing dates in Southern transition zone of Karnataka. Journal of Pharmacognosy and Phytochemistry, 8(1): 2109-2112.

21. Nandini, K.M., Sridhara, S. and Kumar, K. 2018. Effect of different levels of nitrogen on yield, yield components and quality parameters of foxtail millet (Setaria italica L.) genotypes in southern transition zone of Karnataka. International Journal of Chemical Studies, 6(6): 2025-2029.

22. Navya Jyothi, K., Sumathi, V. and Sunitha, N. 2016. Productivity, nutrient balance and profitability of foxtail millet (Setaria italica L.) varieties as influenced by levels of nitrogen. IOSR Journal of Agriculture and Veterinary Science, 9(4): 18-22.

23. Rafi, M.M. and Charyulu, P.B.B.N. 2016. Synergistic effect of Azospirillum and PSB inoculation on growth and yield of foxtail millet. International Journal of Plant, Animal and Environmental Sciences, 6(1): 138-147.

24. Rafi, M.M., Varalakshmi, T. and Charyulu P.B.B.N. 2012. Influence of Azospirillum and PSB inoculation on growth and yield of Foxtail Millet. J. Microbiol. Biotech. Res., 2(4): 558-565.

25. Ramyasri, K., A.V. Ramana, A. Upendra Rao and Guru Murthy, P. 2018. Nutrient uptake vis-a-vis grain yield of foxtail millet varieties as influenced by nitrogen levels in rice fallows. Int. J. Curr. Microbiol. App. Sci., 7(09): 26262629.

26. Reddy, M.U.M., Roja, M., Reddy, M.D. and Barman, S. 2019. Effect of Nitrogen and Phosphorus Management on Growth and Yield of Foxtail Millet (Setaria italica L.) During Summer Season in Odisha, India. Indian J. Agric. Res., 54(2): 242-246.

27. Selectstar Marwein, B., Singh, R. and Chhetri, P. 2019. Effect of integrated nitrogen management on yield and economics of foxtail millet genotypes. Int. J. Curr. Microbiol. App. Sci., 8(08): 2543-2546.

28. Shwethanjali, K.V., Kumar Naik, A.H.T., Naik, B. and Dinesh Kumar, M. 2018. Effect of groundnut + millets intercropping system on yield and economic advantage in central dry zone of Karnataka under rainfed condition. Int. J. Curr. Microbiol. App. Sci., 7(9): 2921-2926.

29. Upendranaik, P., Rao, S., Desai, B.K., Krishnamurty, D. and Yadahalli V.G. 2018. Effect of Different Sources of Organic Manures on Growth and Yield of Foxtail Millet (Setaria italica L.) under Integrated Organic Farming System. Advances in Research, 13(2): 1-6.

30. Vanithasri, J., Kanchana, S., Hemalatha, G., Vanniarajan, C. and Sahul Hameed, M. 2012. Role of millets and its importance in new mellinium. Int. J. Food Sci. Technol., 2(1): 35- 47. 